\title{
The COSEVAST Study: Unravelling the role of Arterial Stiffness in COVID-19 Disease severity
}

\author{
Dr.Sanjeev Kumar *, MS,MCh,Dr.Neeraj Kumar, M.D., Dr.Abhyuday Kumar, MD, Dr.Divendu Bhushan, MD, Dr.Amarjeet \\ Kumar, MD, Dr.Ajeet Kumar, MD, Dr.Veena Singh, MS,MCh, Dr.Prabhat Kumar Singh, MD.
}

All India Institute of Medical Sciences, Patna, INDIA

\begin{abstract}
Background: Based on the detailed review of avail- able research and case studies reported in reputed international journals, it can be concluded that endothelial damage (Endotheliitis) both in small and large arteries may be an important factor of morbidity and mortality in COVID-19 patients. Arterial stiffness due to Endothelial Dysfunction has been established as an independent and specific marker of various chronic cardiovascular diseases.

Objective: Our objective was to examine functional impairment of the arteries in COVID- 19 disease and establish the noninvasive measurement of Arterial Stiffness as an independent marker of disease severity.

Methods: We recorded the Arterial Stiffness of 23 Mild, 21 Moderate and 20 Severe COVID-19 patients grouped on latest NIH severity criteria. We observed Arterial Stiffness of COVID- 19 patients with standard parameters like non-invasive CarotidFemoral Pulse Wave velocity (cfPWV), Age-Normalized increase in cfPWV (ANI_cfPWV).

Results: Moderate and Severe COVID-19 patients have extremely elevated arterial stiffness than Mild patients. In Mild patients, cfPWV $(829.1 \pm 139.2 \mathrm{~cm} / \mathrm{s})$ was extremely significantly lower than both Moderate $(1067 \pm 152.5 \mathrm{~cm} / \mathrm{s}, \mathrm{P}<0.0001)$ and Severe $(1416 \pm 253.9 \mathrm{~cm} / \mathrm{s}, \mathrm{P}<0.0001)$ patients. ANI_cfPWV in Moderate and Severe patients was significantly higher than Mild patients. (Mild: $101.2 \pm 126.1 \mathrm{~cm} / \mathrm{s}$; Moderate: $279 \pm 114.4$ $\mathrm{cm} / \mathrm{s}$; Severe: $580.1 \pm 216.4 \mathrm{~cm} / \mathrm{s}$; intergroup $P<0.0001$ ). Conclusion: Our findings strongly suggest that arterial stiffness can be an independent and accurate marker for objective risk stratification and therapeutic alleviation of the acute cardiovascular complications like MODS in COVID-19.
\end{abstract}

Keywords : COVID-19, Endotheliitis, Arterial Stiffness, Pulse Wave Velocity, Severity, Cardiovascular Complications, Multiple Organ Dysfunction Syndrome (MODS)

Correspondence:

* First Author Corresponding Author: Dr. Neeraj Kumar, M.D.; Affiliation: Assistant Professor; Full Address: Room no.503, 5th Floor, OT Complex IPD, B-Block, Clinical coordinator-COVID-19, All India Institute of Medical Sciences (AIIMS), Patna, Bihar, India PIN 801505 drneerajk@aiimspatna.org; Neeraj.jlnmc@gmail.com

\section{Background}

The acute respiratory viral infection caused by severe acute respiratory syndrome coronavirus 2 (SARS-CoV-2) is named as Corona Virus Disease 2019 (COVID-19) and is declared as a pandemic by the World Health Organization (WHO). As of first week of December 2020, there are around 9.5 million confirmed cases of COVID-19 in India alone, including more than 130,000 deaths. There is a rise in the number of cases every day, affecting millions of people around the globe and resulting in a public health emergency. Moreover, medical professionalsarefindingitverydifficulttomanagethedis- ease in terms of treatment options. Many drugs have been tried under emergency use authorization like Remdesivir or convalescent plasma without much success. Preventive measures like vaccines are being discovered and some are in advanced stages of testing.[1] There is an urgent need to stratify the risk, guide the therapy in a proper manner and con- trol the short and long term complications like target organ damage. Although this disease primarily looks like an acute pulmonary disease, the manifestation of cardiovascular damage strongly suggests that there is an arterial involvement. Various studies have pointed to severe and acute endothelial damage in moderate to severe cases of COVID-19. There is a need to clearly establish relationship between the arterial damage and severity in such patients to improve understanding of the pathophysiology of the disease. Such evidence may radically changethetherapeuticstrategyorgiveriseto a new therapy to improve the prognosis and lessen the burden on the healthcarefacilitiestoalargeextent.

\section{Introduction}

Ithas been extensively highlighted thatSARS-CoV-2 affects the RAS (Renin-Angiotensin System) and the Angiotensin converting enzyme-2 receptors play most important role in presentation of the COVID-19 disease. [2-5] SARS-CoV-2 infects the host using the Angiotensin Converting Enzyme 2 (ACE2) receptor, which is expressed in several organs, including the lung, heart, kidney, brain and intestine. This is due to the fact that ACE2 is a type I membrane protein ex- pressed on endothelial cells in the kidney, heart, gastrointestinal tract, blood vessels, and, importantly, lung AT2 alveolar epithelial cells, which are particularly prone to viral infection. In COVID19 , Sepsis is observed as the most important cause of target organdamageleadingtomorbidityandsub- sequentmortality. As SARS-CoV-2 is a new coronavirus, and its cardiovascular complications and the underlying pathology is still emerg- 
medRxiv preprint doi: https://doi.org/10.1101/2020.12.18.20248317; this version posted December $19,2020$. The copyright holder for this preprint (which was not certified by peer review) is the author/funder, who has granted medRxiv a license to display the preprint in perpetuity. All rights reserved. No reuse allowed without permission.

ing. However, it is accepted that the virus affects the total vasculature in human body and this infection becomesa highly accelerated process for the target organ damage. In the case of acute cardiological manifestation, it is termed as Acute COVID-19 Cardiovascular Syndrome (ACovCS) by the AmericanHeartAssociation'swhitepaper.[6]

European Society of Cardiology (ESC) has published a detailed review paper [7] on the involvement of various cardiovascular target organs in COVID-19 disease. This re- view clearly establishes a close two-way relationship between COVID-19 disease and all cardiovascular diseases (CVD). Even though clinical symptoms of the disease with initial infection show respiratory distress and severe pneumonia, in the later stages the complete cardiovascular system gets affected with direct and indirect damage to other organs dependant on it. The prognosis is even worse in the patients with pre-existing cardiovascular system involvement. Cardiovascular involvement in COVID -19 is seen as key manifestations. In particular, the endothelial cells or pericytes inflammation could lead to severe microvascular and macrovasculardysfunction. EverystageofCOVID-19diseasewhich leads to heart or similar target organ failure shows arterial involvement, basically starting from endothelial cell involvement. In COVID-19, Sepsis is observed as the most important cause of target organ morbidity and subsequent mortality. In Sepsis, the severity is directly associated with Endothelial dysfunction. ItmaybededucedthatpathophysiologyofSep- sis is mainly dependent on level of integrity and functioning endothelium. Hence an objective assessment of Endothelial function may serve as a more accurate prediction tool and a target for therapies aimed at ameliorating Sepsis occurring in laterstagesofCOVID-19.

ThebestwaytoassessEndothelialDysfunctionisassessment of its clinical manifestation, i.e. increase in the ArterialStiff- ness. Therehavebeenmultipleinvitroand invivostudies which have shown that the vascular endothelium is an important factor in setting the vascular tone and endothelial dysfunction leads to arterial stiffness.[8] Arterial stiffness and enhanced wave reflections are markers of cardiovascular dis- ease and independent predictors of cardiovascular risk.[9-12] Stiffening of the large arteries and enhanced wave reflections lead to increased left ventricular (LV) afterload, disturbed coronary perfusion, and mechanical fatigue of the arterial wall.[13]

The relationship between systemic inflammation and arterial stiffness is well established in the literature.[14] The cause-and-effect relationship that acute systemic inflammation leads to deterioration of large-artery stiffness. Given the importance of aortic stiffness for cardiovascular function and risk, the therapeuticinterventions with anti-inflammatory properties will be potentially very useful in reducing the COVID-19morbidityandmortality.

Findings in a study [15] on induced inflammation have shown that thatanacuteinflammationcausedatemporaryincrease in central blood pressure and arterial stiffness in terms of Pulse Wave Velocity. This implies the increased risk of cardiovascular eventsassociatedwith acute systemic inflamma- tion intheCOVID-19.

COVID-19 disease related worldwide research and proposed mechanisms pointed to patho-physiological involvement of endothelial dysfunction and arterial wall compromise. However, there was no empirical evidence of the functional compromiseofarterialwalls.

Hence, a study was urgently needed to study increase in Arterial Stiffness in COVID-19 patients due to systemic inflammation so as to stratify the risk and mitigate further cardiovascular damage with guided therapeutic treatment based on severityofarterialstiffness.

This pressing need is justified by a comprehensive review article [16] published after the present study was envisaged. We hope that the findings from our study will fulfill the need to a largeextent.

\section{Materials and Methods}

The present prospectivenon-randomized observational study titled - "To study the relationship of COVID-19 SEVerity with Arterial STiffness : A prospective cross sectional study" ('COSEVAST study') was conducted in the COVID-19 ICU, Medical ICU and various wards of dedicated Covid hospital at AlIMS, Patna, Bihar, India. The study protocol, informed consents and other trial-related documents received the written approval of Institutional Ethics Committee (IEC No. AlIMS/Pat/IEC/2020/595) AlIMS Patna,Bihar,India. The study design was registered with the Clinical Trials Registry of India(CTRINo. CTRI/2020/10/028489).

All COVID-19 patients were subject to RT-PCR test and had a confirmed infection of SARS-Cov-2 virus. Participants, after understanding the study protocol and procedures, gave their written informed consent for the study. The exclusion criteria were known history of any of these diseases - Di- abetes Mellitus (DM), Hypertension (HTN), CAD, Stroke, Neuropathy, PAD, Nephropathy, MI, Pregnancy, Peripheral Oedema or inflammation, Cardiac arrhythmia and any preexistingCardiovasculardisorder.

Patient Categorization. The selected patients after fulfillingtheinclusioncriteriaweregroupedintothreecategories - Mild, Moderate and Severe category based on latest NIH Guidelines[17]as-

A. Mild category: Individuals with mild signs and symptoms like fever, cough, sore throat, malaise, headache, muscle pain, nausea, vomiting, diarrhea, loss of taste and smell but who do not have shortness of breath, dyspnea, or abnormal chestimaging.

B. Moderate category: Individuals who show evidence of lower respiratory disease during clinical assessment or imaging and who have saturation of oxygen (SpO2) 94\% on room air atsealeveland

C. Severe category: Individuals who have saturation of oxygen $(\mathrm{SpO} 2)<94 \%$ on room air at sea level, a respiratory rate of $>30$ breaths/min, $\mathrm{PaO} 2 / \mathrm{FiO} 2<300 \mathrm{mmHg}$, or lung infiltrates $>50 \%$.

The range of treatment protocols followed in this study 
were based on our institutional standard operating procedure(SOP) forthemanagement ofCOVID-19patientsbased on their clinical severity category and it included antivirals (Remdesivir), broad spectrum antibiotics, low molecular weight heparin (Enoxaparin) immunomodulators (steroids, Tocilizumab) and supportive management (oxygen via nasal cannula, face mask, non-rebreathing face mask; non-invasive orinvasivemechanicalventilation;awakeproning).

Measures of Arterial Stiffness. With theincreasedawareness about Arterial Stiffness during pre-Covid era, clinicians have started adding measurement and treatment of underlying arterial stiffness in their clinical practice.[18] International healthcare societies like the European Society of Hypertension (ESH) and European Society of Cardiology (ESC) have included PWV measurement in their 2003 guidelines for managementofhypertension. [19,20]

Arterial stiffness assessed by PWV (pulse wave velocity) correlates to the number of treated and non-treated cardiovascularriskfactors, atheroscleroticeventsandcardiovascularrisk as predicted by the Framingham risk equations.[21] PWV is also positively correlated with carotid intima media thick- ness, a marker of atherosclerotic burden in the coronary arteries.[22] Inthisstudy, Arterialstiffnessis primarilymeasured in terms of pulsewavevelocity, whichisarecognizedgold standard.

Pulse wave velocity, which is a relevant indicator of arterial stiffness, can be measured non-invasively with a variety of devices. However, since COVID-19 is a highly con- tagious disease, a fully automatic device with minimal con- tact, lesser exposure time and proximity with the patient need to be maintained.[23] It would be always challenging for observer to conduct the entire test by wearing full Personal Protection Equipment (PPE) kit. So a test device which avoids close proximity, longer exposure and holding a probe while testing, was needed for the study. We found that the medical device PeriScope ${ }^{\mathrm{TM}}$ (Manufactured by M/s. Genesis Medical Systems Pvt. Ltd., Hyderabad, India) was suitable as it fulfilled all the above requirements. PeriScope is a clinically validated and tested the non-invasive medical device used to measure Brachial Ankle PWV (baPWV) and derives the Carotid Femoral PWV (cfPWV), which is equivalent to aortic PWV.[24] A population-based study with 3969 subjects using 'PeriScope' has established the role of arterial stiffness in various cardiovasculardiseases(CVD).[25]Aortic pressure values also have been established as surrogate markers for arterial stiffness. PeriScope estimates the Aortic Pressures and the Systolic Pressure Augmentation(AugP) at the root of the Aorta due to the increased arterial stiffness. The Pressure Augmentation Index (Alx) values found by PeriScope were compared with other internationally accepted non-invasive device and found to be very accurate and highly comparable.[26] All the tests were conducted as per the standard procedure given in the operator's manual of PeriScope. Electrocardiogram (ECG) Electrodes were placed on ventral surface of both wrists and medial side of ankles, and BP cuffs were wrapped on both upper arm brachial artery and tibial artery aboveankles. AlltheECG and pressure recordings were done automatically and data were stored in the personal computer for analysis. The built in validated proprietary algorithm within the PeriScope PC software calculated the following parameters from the waveforms, which were stored in the computer for analysis like - systolic blood pressure (SBP), diastolicblood pressure (DBP), mean arterial pressure (MAP), pulse pressure (PP), heart rate (HR), carotid-femoral pulse wavevelocity(cfPWV).

Data Analysis. Data are expressed as mean \pm SD. Statistical analysis was performed using the GraphPad PRISM software version 5.03 (GraphPad software Inc., San Diego, California, USA). Difference between all the groups were evaluated by unpaired Student's ' $\mathrm{t}$ ' test and ANOVA. Linear regression analysis and Pearson's correlation analysis were performed to evaluate the association between various confounding factors to rule outinterdependence. Probability values of $\mathrm{P}<$ 0.05 were considered to indicate statistical significance. All $P$ valuesaretwo-tailed.

\section{Results}

Total 64 patients $(42 \mathrm{M} / 22 \mathrm{~F})$ patients were recruited in the study. The patient demographic variables were shown in Table 1 . All the patients were under the healthy and normal BMI category. Since the patients did not have any known comorbidity, Lipid profileorBloodsugarlevelswerenottaken into consideration. The minimum age was 18 years and maximum was 69 years. Although there was a difference between the mean values of Age, Weight and height; but it was statistically not significant between the groups. Figure 2 shows the graphical representation of overall patient demographics as age, weight, heightandBMlas(Figure2a,b,candd).

Although Arterial Blood Gas (ABG) Analysis was carried outfor all the patients, it was not possible to find the point- of-time $\mathrm{PaO} 2 \%$ value of each patient at the time of arterial stiffness test. For this reason, stat $\mathrm{SpO} 2 \%$ reading was taken as the measure of Oxygen saturation for accurate comparison. Also, since it was not ethically correct[27] and clinically possible to check oxygen saturation without or by removing external Oxygensupportinallcases, thebestwaytoquantify theseverity was taking ratio of $\mathrm{SpO} 2 \%$ and $\mathrm{FiO} 2 \%$ as an indication of respiratory distress. Earlier studies and guidelines suggest SpO2\%toFiO2\%(SF)ratioisareliablenoninvasive surrogatefor $\mathrm{PaO} 2 \%$ to $\mathrm{FiO} 2 \%$ (PF) ratio [28-30] especially in COVID-19 patients. All of the Severe patients were admitted into the COVID-19ICU whereas all of the Mild patients were admitted into COVID-19 and General wards. Some of the Moderate patientswereinthelCUandsomewereinthe Generalwardwith Oxygen support. The statistical analysis of the segregation criteria is asshown in Table2. The Patient categorization can be clearly visualized by graphical representation (Figure 3) of the data. The Figure 3 a shows statis- tical analysis of respiration rate of the three groups, Figure $3 \mathrm{~b}$ shows FiO2\%, Figure 3c shows SpO2\% whereas Figure 3d shows the statistical analysis ofSFratio(SpO2/FiO2)respectively. 
medRxiv preprint doi: https://doi.org/10.1101/2020.12.18.20248317; this version posted December 19, 2020. The copyright holder for this preprint (which was not certified by peer review) is the author/funder, who has granted medRxiv a license to display the preprint in perpetuity.

All rights reserved. No reuse allowed without permission.

CARDIO VASCULAR RISK ANALYSIS

\begin{tabular}{|c|c|c|c|c|c|}
\hline \multirow{3}{*}{$\begin{array}{l}\text { INTERPRETATION SUMMARY* } \\
\text { Est. Functional Vascular Age : } 69 \text { to } 71 \text { yrs } \\
\text { Insufficient data input for FRAMINGHAM risk analysis }\end{array}$} & \multicolumn{5}{|c|}{ TEST REPORT AND OBSERVATIONS } \\
\hline & \multirow[b]{2}{*}{ Pararneter } & \multirow[b]{2}{*}{ Unit } & \multirow[b]{2}{*}{ Normal Value } & \multirow[b]{2}{*}{ Observed Value } & \multirow[b]{2}{*}{ Significance ${ }^{*}$} \\
\hline & & & & & \\
\hline & Heart Rate & BPM & 60 to 100 & 69.5 & HR is low-Normal. \\
\hline CARDIOVASCULAR INTERPRETATION* & Blood Pressure & $\mathrm{mmHg}$ & $120 / 80$ & $136 / 88$ & Hi-Normal Blood Pressure \\
\hline \multirow{3}{*}{$\begin{array}{l}\text { Total CardioVascular risk grade :Moderate } \\
\text { with Severe Arterial Stiffness. }\end{array}$} & Pulse Pressure & $\mathrm{mmHg}$ & Less than 50 & 48 & Normal Pulse Pressure \\
\hline & Right baPW & $\mathrm{cm} / \mathrm{s}$ & Less than 1306.56 & 1925.7 & Severe CA Stiffness \\
\hline & Left baPWN & $\mathrm{cm} / \mathrm{s}$ & Less than 1306.56 & 1941.5 & Severe CA Stiffness \\
\hline CLINICAL RECOMMENDATIONS: & C.F PWV & $\mathrm{cm} / \mathrm{s}$ & Less than 868.48 & 1377.9 & Severe Aortic Stiffness \\
\hline \multirow{2}{*}{$\begin{array}{l}\text { Homocysteine test recommended. } \\
\text { HbA1c test may be advisable. }\end{array}$} & R Bra ASI & $\mathrm{mmHg}$ & 20 to 70 & 33.8 & Normal rbASI \\
\hline & L Bra ASI & $\mathrm{mmHg}$ & 20 to 70 & 38.8 & Normal IbASI \\
\hline \multirow{2}{*}{ THERAPEUTIC SUGGESTIONS**: } & R Ank ASI & $\mathrm{mmHg}$ & 20 to 70 & 47.5 & Normal raASI \\
\hline & L Ank ASI & $\mathrm{mmHg}$ & 20 to 70 & 37.3 & Normal laASI \\
\hline \multirow{7}{*}{$\begin{array}{l}\text { Systemic vascular therapy required. : Strong } \\
\text { Consider Medium dose combo:ACEl/ARB/CCB }\end{array}$} & $R-A B I$ & - & 0.9 to 1.35 & 1.12 & ABI Normal:Peripheral ASO may be absent \\
\hline & $L$ - ABI & - & 0.9 to 1.35 & 1.11 & ABI Normal:Peripheral ASO may be absent \\
\hline & Ao Sys & $\mathrm{mmHg}$ & Less than 117 & 125 & Mild increase in Ao Sys \\
\hline & $A_{0} \mathrm{PP}$ & $\mathrm{mmHg}$ & Less than 36 & 39 & Borderline increase in Ao PP \\
\hline & Ao Dia & $\mathrm{mmHg}$ & Greater than 89 & 86 & Mild decrease in Ao Dia \\
\hline & Ao AugP & $\mathrm{mmHg}$ & Less than 7 & 13 & Moderate increase in Ao Aug $\mathrm{P}$ \\
\hline & Alx (Alx@HR75) & $\%$ & Less than $15(17)$ & $34(36)$ & High increase in $A_{0} \mathrm{Alx}$ \\
\hline 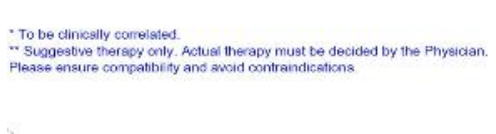 & \multicolumn{5}{|c|}{ 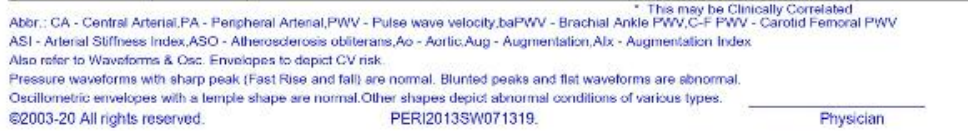 } \\
\hline
\end{tabular}

Fig. 1. Typical PeriScope test report of a Severe Patient in the COVID-19 ICU

\begin{tabular}{|c|c|c|c|c|c|c|c|c|}
\hline \multirow{2}{*}{ Sr. No. } & \multirow{2}{*}{ Parameter } & \multirow{2}{*}{ Mild(1) } & \multirow{2}{*}{ Moderate(2) } & \multirow{2}{*}{ Severe(3) } & \multirow{2}{*}{ All } & \multicolumn{3}{|c|}{ P-value } \\
\hline & & & & & & Grp1-2 & Grp2-3 & Grp1-3 \\
\hline 1 & $\operatorname{Sex}(M / F)$ & $13 / 10$ & $18 / 3$ & $11 / 9$ & $42 / 22$ & - & - & - \\
\hline 2 & Age(yrs) & $37.87 \pm 13.36$ & $45.29 \pm 13.07$ & $50.50 \pm 12.56$ & $44.25 \pm 13.85$ & 0.0701 & 0.2007 & $0.0028^{*}$ \\
\hline 3 & $\mathrm{Wt}(\mathrm{Kg})$ & $61.96 \pm 13.32$ & $70.14 \pm 12.75$ & $59.05 \pm 10.12$ & $63.73 \pm 12.89$ & $0.0438^{*}$ & $0.0038^{*}$ & 0.4307 \\
\hline 4 & $\mathrm{Ht}(\mathrm{cm})$ & $162.8 \pm 8.574$ & $167.9 \pm 8.402$ & $161.7 \pm 7.680$ & $164.1 \pm 8.555$ & 0.0541 & $0.0174^{*}$ & 0.6403 \\
\hline 5 & $\mathrm{BMI}(\mathrm{Kg} / \mathrm{m} 2)$ & $23.18 \pm 3.547$ & $24.78 \pm 3.492$ & $22.47 \pm 2.532$ & $23.48 \pm 3.334$ & 0.1405 & $0.0207^{*}$ & 0.4605 \\
\hline
\end{tabular}

Values areexpressedasMean \pm SD. ${ }^{*}$ Significantdifferenceinmeanvalues.

Table 1. Demographic characteristics as per COVID-19 severity in the present study

\begin{tabular}{|c|c|c|c|c|c|c|c|}
\hline Sr. No. & Parameter & Mild(1) & Moderate(2) & Severe(3) & \multicolumn{3}{|c|}{ P-value } \\
\cline { 5 - 8 } & & & & & Grp1-2 & Grp2-3 & Grp1-3 \\
\hline 1 & Resp.rate(BrPM) & $20.87 \pm 1.180$ & $22.33 \pm 4.139$ & $29.55 \pm 13.19$ & 0.1113 & $0.0219^{*}$ & $0.0031^{*}$ \\
\hline 2 & FiO2(\%) & $21.00 \pm 0.0$ & $35.48 \pm 12.68$ & $57.85 \pm 23.13$ & $<0.0001^{*} \$$ & $0.0004^{*}$ & $<0.0001^{*} \$$ \\
\hline 3 & SpO2(\%) & $97.30 \pm 1.428$ & $96.48 \pm 2.136$ & $96.50 \pm 2.236$ & 0.1350 & 0.7994 & 0.0861 \\
\hline 4 & S/Fratio & $463.4 \pm 6.801$ & $304.1 \pm 101.6$ & $195.9 \pm 82.33$ & $<0.0001^{*}$ & $0.0006^{*}$ & $<0.0001^{*}$ \\
\hline
\end{tabular}

Values areexpressedasMean \pm SD. ${ }^{*}$ Significantdifferenceinmeanvalues. \$Mann-Whitney't'test

Table 2. Categorization criteria as per COVID-19 severity in the present study 
medRxiv preprint doi: https://doi.org/10.1101/2020.12.18.20248317; this version posted December 19, 2020. The copyright holder for this preprint (which was not certified by peer review) is the author/funder, who has granted medRxiv a license to display the preprint in perpetuity.

All rights reserved. No reuse allowed without permission.

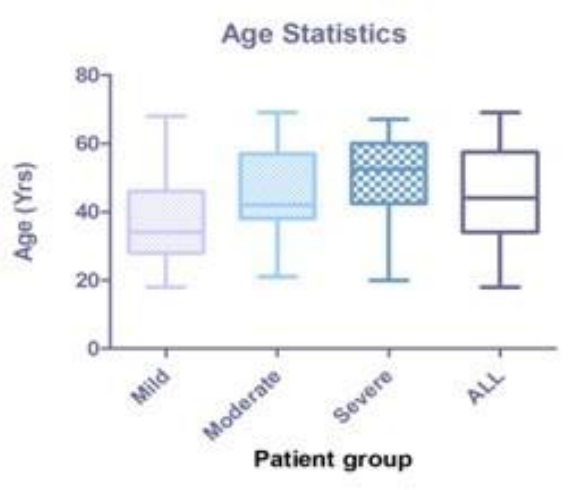

(a)

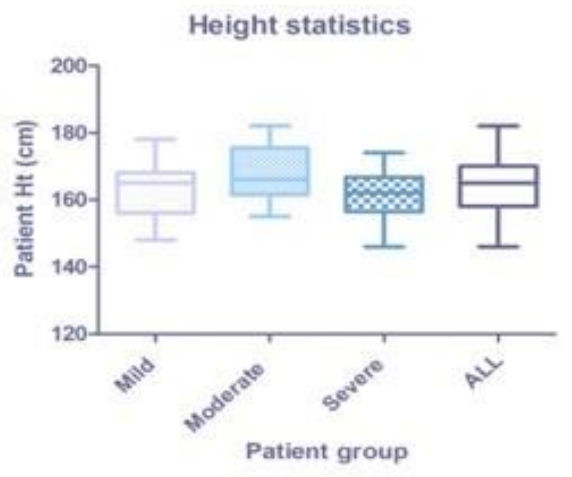

(c)

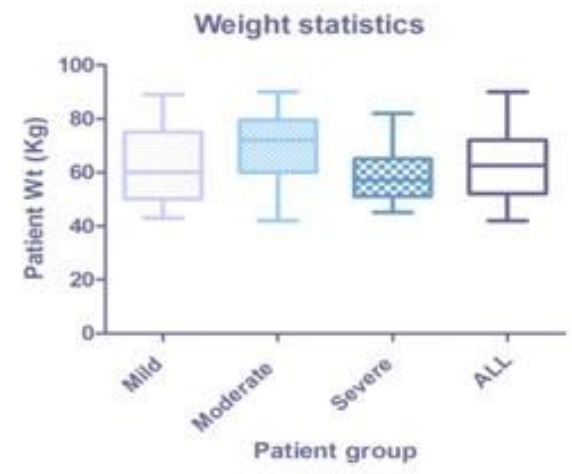

(b)

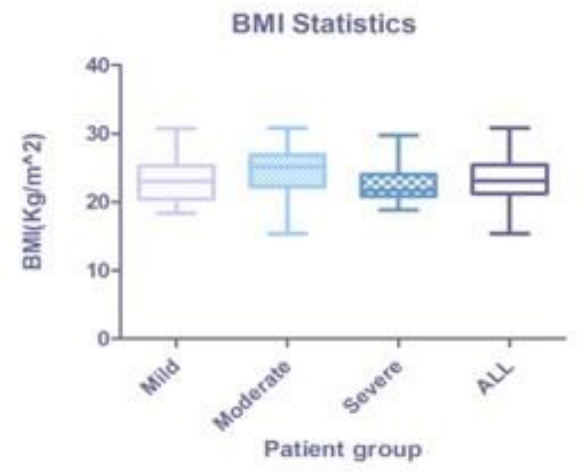

(d)

Fig.2: Patients Demography a. Age, b. Weight, c. Height, d. BMI

Fig. 2

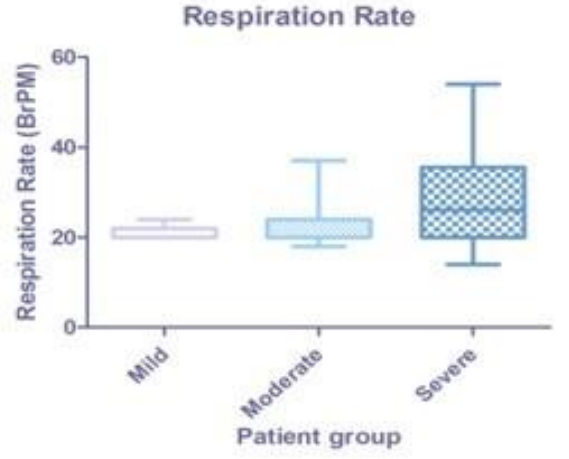

(a)

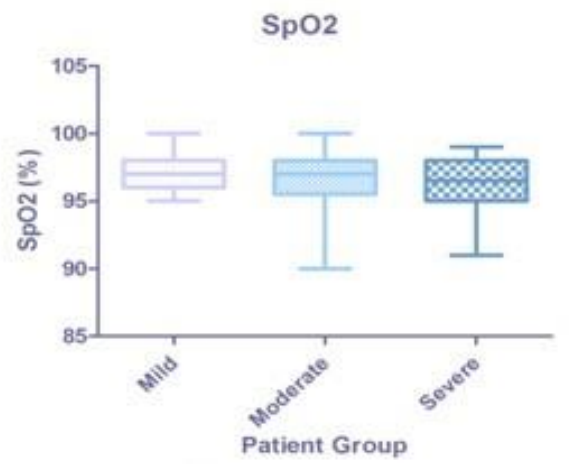

(c)

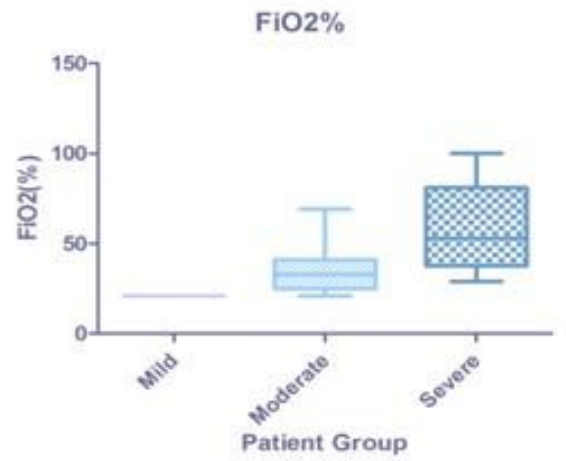

(b)

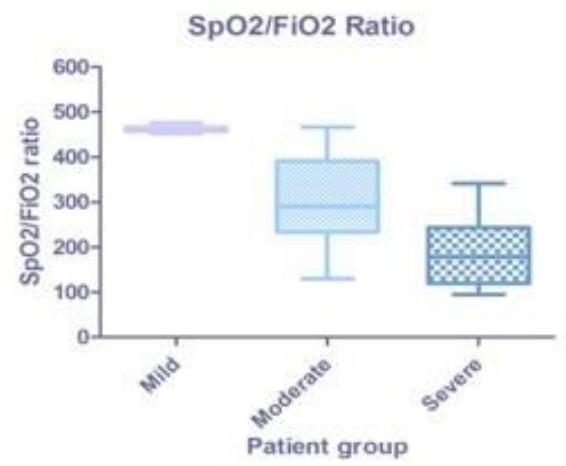

(d)

Fig. 3 Patient Categorization a. Respiration Rate, b. FiO2\%, c. SpO2\%, d. SpO2\%/FiO2\% ratio 
medRxiv preprint doi: https://doi.org/10.1101/2020.12.18.20248317; this version posted December 19, 2020 . The copyright holder for this preprint (which was not certified by peer review) is the author/funder, who has granted medRxiv a license to display the preprint in perpetuity. All rights reserved. No reuse allowed without permission.

Asthe'normal'valuearterialstiffnessisafunction ofaper- son's chronological age [31], (i.e. the normal value of Ar- terial stiffness goes on increasing with age), the real mea- sure of abnormal increase in Arterial stiffness is the differ- ence of the 'predicted' cfPWV value of a 'normal' subject of that age and actually measured cfPWV. Hence, Arterial Stiff- ness was analyzed using the values of Carotid Femoral Pulse Wave velocity (cfPWV) and increase in cfPWV from the age dependent normal value. Also, in our study, the regression analysis between cfPWV and HR showed very low correla- tion (Multipler $=0.2180, r \hat{2}=0.04754, P=0.0835$ ). Hence, theeffect of HR on cfPWV values is negligible. It can very safely be stated that the findings about arterial stiffness from the study are independent of effect of HR. No other param- eters like Heart rate or Pulse Pressure showed consistent in- crease in their mean values between Mild, Moderate and Se- vere groups. Heart Rate (Mild: $76.06 \pm 14.47 \mathrm{BPM}, 95 \% \mathrm{Cl} 69.81$ to 82.32 ; Moderate:78.20 $\pm 17.20 \mathrm{BPM}, 95 \% \mathrm{Cl} 70.36$ to86.03;Severe:98.07士18.58BPM95\%Cl89.37to106.8), BrachialPulsePressure(Mild: $38.04 \pm 7.957 \mathrm{mmHg}, 95 \%$ Cl34.60to41.48; Moderate:45.95 $\pm 9.113 \mathrm{mmHg}, 95 \% \mathrm{Cl}$

41.80to50.10;Severe:42.40 $\pm 12.09 \mathrm{mmHg}, 95 \% \mathrm{Cl} 36.74$ to 48.06$)$ respectively. Refer Fig. 4 for the graphical comparison.

On the other hand, the differences in the measurements of Arterial Stiffness parameters were extremely significant in all three groups. All the Arterial stiffness measurements showed uniformity in trends and almost same rise as per the severity of COVID-19 disease. More importantly, since no confounding factor or dependent parameter was found in the statistical analysis of the data, Arterial Stiffness measures stood out as independent and consistent indicators of severity grade. The analysis of Arterial Stiffness parameters is as given in Table 3 . These results can be properly visualized in comparison with the earlier graphs. Figure 5 gives a clear idea about the extremely statistically significant elevation of all Arterial Stiffness measurements across patient groups. The Figure $5 a$ shows values of cfPWV in all three patient categories. Figure 5b shows Age Normalized increase in cfPWV.

\section{Discussion}

The SARS-CoV-2 virus uses the same system of cell en- try, which is triggered by binding of the viral spike $(S)$ pro- tein to angiotensin-convertingenzyme2(ACE2) on the sur- face of the host cell. It is clearly evident that the full en- dothelial layer is affected throughout the body and the dis- ease called Endotheliitis sets in due to COVID-19 infection. The Lancet article[33] shows clear images with endothelial layer involvement. Chen Tetal [34] in their epidemiologi- calstudies show that COVID-19 patients admitted to hospi- tal or to an intensive care unit (ICU) present frequently with accompanying conditions such as advanced age, hypertension, diabetes, and cardiovascular diseases implying compromised endothelial integrity may be playing a major part in COVID-19mortality. Acutebilaterallimbischaemia(ALI) was observed in young and seemingly healthy patients without any history of atherosclerosis, atrial fibrillation, or preexisting blood clotting disorders indicating that COVID-19 infection might increase the incidence of ALI and be associated with poorer surgical results owing to the associated acquired hypercoagulability. [35] Explaining the potential role of Endothelial Dysfunction and endothelial layer compromiseinCOVID-19, thearticleinCardiovascularResearch [36] shows that Chronic Endothelial Dysfunction may lead to acute vascular inflammation under the attack of SARS- CoV-2 Virus. Prior chronic Endothelial impairment and/or direct viral infection of endothelial cells may work in tandem into a breakdown of endothelial function. Since endothelial layer is present everywhere throughout the vascular system in nonfenestrated form (in the arteries, lungs or the Heart), continuous non-fenestrated form (in the kidneys) and in the discontinuous form (in the liver), the acute endothelial function failure may lead to pathogenesis of sudden severe conditions in various organs. It may manifest as pneumonia and ARDS in the respiratory system, induce microcirculation disorders/myocardial injury in the heart, translate into activation of the coagulation pathway causing thrombosis or develop into tissue damage in the brain and in the Kidneys. The over- all vasculature is affected very quickly by this disease. The cfPWV which we observed in severe COVID-19 patients was higher than the cfPWV in patients with long term chronic diseases like ESRD, CAD, DM etc. For example, in CAD patients, it was $1204 \pm 301.8 \mathrm{~cm} / \mathrm{s}$. [24-25] This indicates that COVID-19 damage to the vasculature within less than 15 days is comparable to the damage caused byCAD in number of years. Our COSEVAST study had very strict exclusion criteria. All patients with known Diabetes and Hyperten- sion were excluded. Patients with all other cardiovascular diseases and related surgical intervention/ therapy were ex- cluded. Patients with high obesity, history of smoking were also excluded. This was necessary to eliminate basal devia- tion of arterial Stiffness from the Normal vasculature. These exclusions reduced the total number of study subjects but removed any selection bias and amplified the validity of our findings. A similar large scale, longitudinal, multi-centric study (COVID-19 ARTErial Stiffness and vascular AgiNg CARTESIAN Study) [37] has been proposed and our study will try to follow harmonization with that study. Based on the findings of the present COSEVAST study, another interventional study will be undertaken in the near future to assess various drugs to reduce the abnormal increase of arterial stiffness in COVID-19 patients. The proposed study will bevery helpful in establishing the most efficacious ther- apy in reducing COVID-19 complications. To the best of our knowledge, this is the first study to independently observe significant functional changes in vasculature due to arterial inflammation in COVID-19 patients in terms of non-invasive measuresofArterialstiffness.

\section{Limitations}

As for the limitations, any of the patients did not abstain fromthestandardtherapytoalleviatetheCOVID-19disease 
medRxiv preprint doi: https://doi.org/10.1101/2020.12.18.20248317; this version posted December $19,2020$. The copyright holder for this preprint (which was not certified by peer review) is the author/funder, who has granted medRxiv a license to display the preprint in perpetuity.

All rights reserved. No reuse allowed without permission.

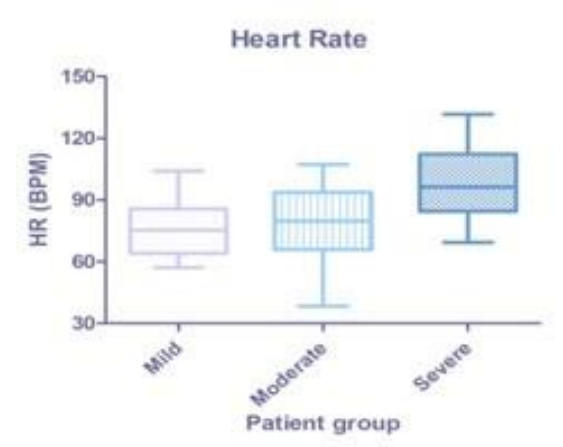

(a)

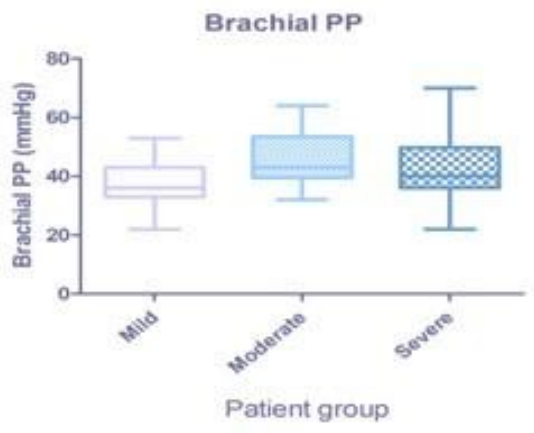

(b)

Fig.4 Related measurements in the study - a. Heart Rate, b. Brachial Pulse Pressure

\begin{tabular}{|c|c|c|c|c|c|c|c|}
\hline \multirow{2}{*}{ Sr. No. } & \multirow{2}{*}{ Parameter } & \multirow{2}{*}{ Mild(1) } & \multirow{2}{*}{ Moderate(2) } & \multirow{2}{*}{ Severe(3) } & \multicolumn{3}{|c|}{ P-value } \\
\hline & & & & & Grp1-2 & Grp2-3 & Grp1-3 \\
\hline 1 & cfPWV(cm/s) & $829.1 \pm 139.2$ & $1067 \pm 152.5$ & $1416 \pm 253.9$ & $<0.0001^{*}$ & $<0.0001^{*}$ & $<0.0001^{*}$ \\
\hline 2 & cfPWVincrease\#(cm/s) & $101.2 \pm 126.1$ & $279 \pm 114.4$ & $580.1 \pm 216.4$ & $<0.0001^{*}$ & $<0.0001^{*}$ & $<0.0001^{*}$ \\
\hline
\end{tabular}

ValuesareexpressedasMean $\pm S D$. $*$ Significantdifferenceinmeanvalues.\#AgeNormalized.

Table 3. Patient Arterial Stiffness measures as per COVID-19 severity in the present study

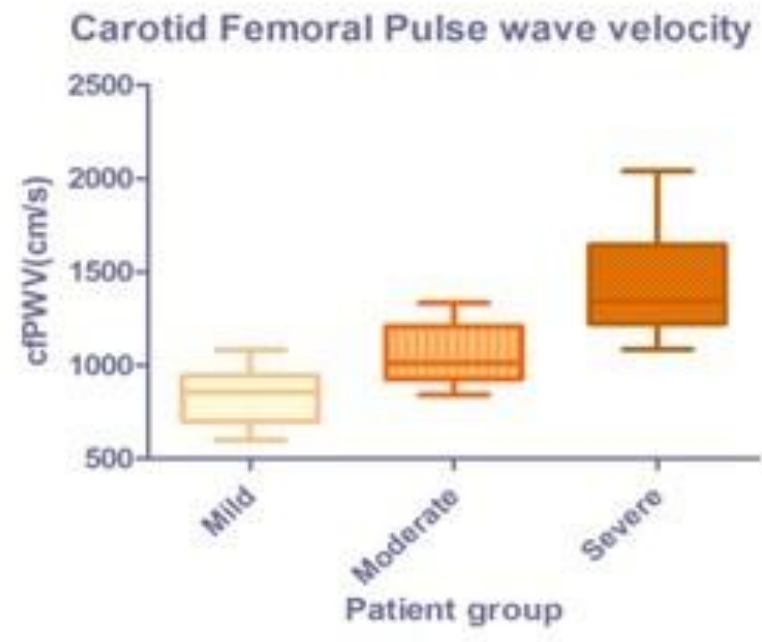

(a)

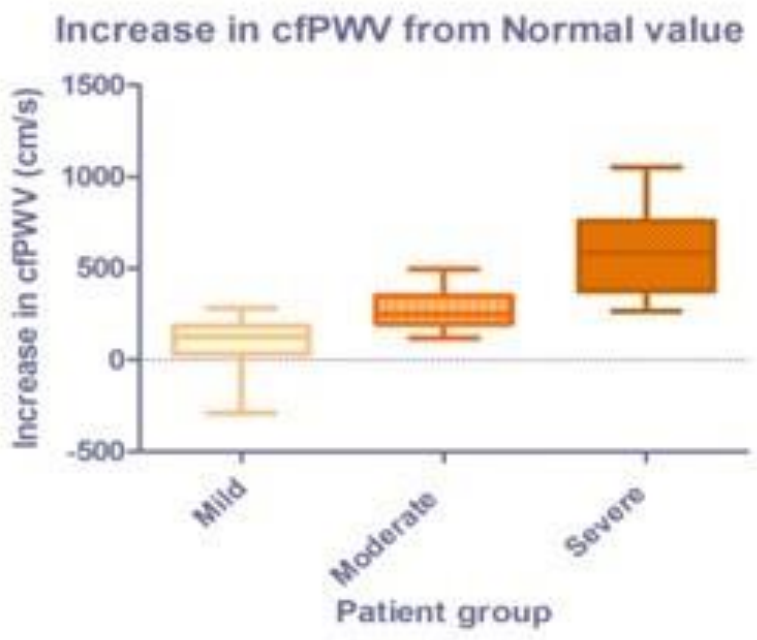

(b)

Fig. 5 Arterial Stiffness measurements of COVID-19 Patients a. cfPWV, b. Age normalized increase in cfPWV 
medRxiv preprint doi: https://doi.org/10.1101/2020.12.18.20248317; this version posted December 19, 2020. The copyright holder for this preprint (which was not certified by peer review) is the author/funder, who has granted medRxiv a license to display the preprint in perpetuity.

All rights reserved. No reuse allowed without permission.

symptomssinceitwasonlyanobservationalstudy. Thesam- ple size were very small. However, the therapy was uniform intragroup and did not include any drug which could alter the arterial stiffness of the patents. Especially, the therapy of Moderate and Severe groups was identical except the difference in Oxygen supplementation volume. We wanted to conduct multiple follow-up tests to find any trends in Arte- rial Stiffness, however it proved almost impossible to study patients with COVID-19 diseasebecause ofvariousreasons like changing status of the patient condition, restrictions on research staff movements and sometimes unfortunate death of the patients during the study. We are also in the process of undertaking a medium-term follow-up study of the patients in the present study after their discharge. These subjects will be observed for changes in Arterial Stiffness and occurrence of Cardiovascular disease, if any, over a period of 12 months with thePeriScopedevice.

\section{Conclusions}

The results of this study establish non-invasive measurement of Arterial Stiffness as an independent severity marker in COVID-19 patients. It also strongly indicates that regular assessment and regulation of Arterial Stiffness by titration of therapeutics may reduce acute cardiovascular complications andmortalityinCOVID-19patientssignificantly.

\section{Authors' Contributions}

Dr. Sanjeev Kumar: Supervision, Project administration, writing- reviewediting

Dr. NeerajKumar: Conceptualization, datacuration,formal analysis, writing-originaldraft, writing-review editing Dr. AbhyudayKumar:Methodology,datacuration,writingreview editing

Dr.DivenduBhushan:Methodology,datacuration,writingreview editing

Dr. AmarjeetKumar: Methodology, datacuration, writingreview editing

Dr. AjeetKumar: formalanalysis,writing-review editing Dr. Veena Singh: writing-review editing

Dr.PrabhatKSingh:Conceptualizationsupervision, visualization.

\section{Conflict of Interest}

Alltheauthorsdeclarenoconflictofinterest.

\section{Funding}

Noexternalfunding. 
medRxiv preprint doi: https://doi.org/10.1101/2020.12.18.20248317; this version posted December 19, 2020 . The copyright holder for this preprint (which was not certified by peer review) is the author/funder, who has granted medRxiv a license to display the preprint in perpetuity. All rights reserved. No reuse allowed without permission.

\section{References}

1. Sarvepalli D. Coronavirus Disease 2019 A Comprehensive Review of Etiology, Pathogenesis, Diagnosis, and Ongoing ClinicalTrials. Cureus. 2020;12(5):e8076. Published2020 May 12.doi:10.7759/cureus.8076

2. Shang, J., Ye, G., Shi, K. et al. Structural basis of receptor recognition by SARS-CoV-2. Nature 581, 221-224 (2020). https://doi.org/10.1038/s41586-020-2179-y

3. Markus Hoffmann, et al. SARS-CoV-2 Cell Entry Depends on ACE2 and TMPRSS2 and Is Blocked by a Clinically Proven Protease Inhibitor, Cell, Volume 181, Issue 2,2020, Pages 271-280.e8,ISSN 0092-8674, https://doi.org/10.1016/j.cell.2020.02.052.

4. Gheblawi $M$, Wang $K$, Viveiros $A$, et al. AngiotensinConverting Enzyme 2: SARS-CoV-2 Receptor and Regulator of the Renin-Angiotensin System: Cel- ebrating the 20th Anniversary of the Discovery of ACE2. Circ Res. 2020;126(10):1456-1474.

doi:10.1161/CIRCRESAHA.120.317015

5. Zemlin AE, Wiese OJ. Coronavirus disease 2019 (COVID-19) and the renin-angiotensin system: A closer look at angiotensin-converting enzyme 2 (ACE2). Ann Clin Biochem. 2020;57(5):339-350.

doi:10.1177/0004563220928361

6 . Nicholas S.et al.Description and Proposed Management of the Acute COVID-19 Cardiovascular Syndrome Circulation. 2020; 141:1903-1914. DOI: 10.1161/CIRCULATIONAHA.120.047349

7. Guzik et al. COVID-19 and the cardiovascular system implications for risk assessment, diagnosis, and treatment optionsCardiovascRes.doi:10.1093/cvr/cvaa106

8. Daniel A. Duprez Arterial Stiffness and Endothelial Function Key Players in Vascular Health HypertensionVolume 55, Issue 3, 1 March 2010, Pages 612-61 https://doi.org/10.1161/HYPERTENSIONAHA.109.144725

9. Stefanadis C, Dernellis J, Tsiamis E, Stratos C, Diamantopoulos L, Michaelides A, Toutouzas P.Aortic stiffness is a risk factor for recurrent acute coronary events in patients with ischaemic heart disease. Eur Heart J. 2000;21:390

$-396$.

10. Stefanadis C, Wooley CF, Bush CA, Kolibash AJ, Boudoulas H. Aortic distensibility abnormalities in coronary arterydisease.AmJCardiol.1987;59:1300-1304.

11. Blacher J, Asmar R, Djane S, London GM, Safar ME. Aortic pulse velocity as a marker of cardiovascular risk in hypertensivepatients. Hypertension.1999;33:1111-1117.

12. LaurentS, BoutouyrieP,AsmarR, Gautier I, LalouxB, Guize $L$, Ducimetiere $P$, Benetos A. Aortic stiffness is an independent predictor of all-cause and cardiovascular mortalityinhypertensivepatients. Hypertension. 2001;37:1236 $-1241$.

\section{NicholsWW,O'RourkeMF,editors.McDonald'sBlood}

Flow in Arteries. 4th ed. London, UK: Edward Arnold; 1998:170-222,284-315,347-395,450-476. 11

14. Jae et al. Acute Systemic Inflammation Increases Central Blood Pressure and Pulse Wave Velocity in Healthy Subjects Circulation. 2009;120:S1006
15. Vlachopoulos et al. Acute Systemic Inflammation Increases Arterial Stiffness and Decreases Wave Reflections in HealthylndividualsCirculation.2005;112:2193-2200

16. Matthew A et al. Severe Acute Respiratory Syndrome Coronavirus 2, COVID-19, and the ReninAngiotensin System. Hypertension 2020; 76:1350-1367. https://doi.org/10.1161/HYPERTENSIONAHA.120.15948

17. Clinical Presentation of People with SARS-

CoV-2 Infection Last Updated: October 9, 2020 https://www.covid19treatmentguidelines.nih.gov/overview/clinic al-presentation/

18. European Society of Hypertension-European Society of Cardiology guidelines for the management of arterial hypertension: Guidelines Committee. J Hypertens.2003;21:1011-53.

19. 2007 Guidelines for the Management of Arterial Hypertension the Task Force for the Management of Arterial Hypertension of the European Society of Hypertension (ESH) and of the European Society of Cardiology (ESC) J Hypertens.2007;25:1105-87.

20. Vogel RA, Benitez RM. Noninvasive assessment of cardiovascular risk: From Framingham to the future. Rev CardiovascMed2000;1:34-42.

21. Wofford JL, Kahl FR, Howard GR, McKinney WM, Toole JF, Crouse JR 3rd. Relation of extent of extracranial carotid artery atherosclerosis as measured by B-mode ultra- sound to the extent of coronary atherosclerosis. Arterioscler Thromb 1991;11:1786-94.

22. Khoshdel AR, CarneySL, Nair BR, Gillies A. Better managementofcardiovasculardiseasesbypulsewavevelocity: Combiningclinicalpracticewithclinicalresearchusing evidence-based medicine. Clin Med Res. 2007;5:45-52. 23.Interim Infection Prevention and Control Recommendations for Healthcare Personnel During the Coronavirus Disease 2019 (COVID-19) Pandemic https://www.cdc.gov/coronavirus/2019-

ncov/hcp/infection- control-recommendations.html

24. Naidu MU, Reddy BM, Yashmaina S, Patnaik AN, Rani PU. Validity and reproducibility of arterial pulse wave velocity measurement using new device with oscillometric technique: Apilotstudy.BiomedEngOnline.2005;4:49.

25. Shridhar $Y$, Naidu MU, Usharani P, Raju YS. Noninvasive evaluation of arterial stiffness in patients with increased risk of cardiovascular morbidity: A cross sectional study.IndianJPharmacol.2007;39:294-8.

26. Naidu M.U.R., Reddy C Prabhakar Non-invasive measurement of aortic pressure in patients: Comparing pulse wave analysis and applanation tonometry Indian J Pharmacol.2012;44:2:230-23312

27.ETHICAL GUIDELINES FOR BIOMEDICAL RE- SEARCH ON HUMAN PARTICIPANTS INDIAN COUN- CIL OF MEDICAL RESEARCH NEW DELHI 2006

https://main.icmr.nic.in/sites/default/files/guidelines/ethical_guidelines 0.p

28. Lu,X.,Jiang,L.,Chen, T.etal. Continuouslyavailable ratio of SpO2/FiO2 serves as a noninvasive prognostic marker for intensive care patients with COVID-19. Respir Res 21, 194 (2020). https://doi.org/10.1186/s12931- 020- 
medRxiv preprint doi: https://doi.org/10.1101/2020.12.18.20248317; this version posted December 19, 2020. The copyright holder for this preprint (which was not certified by peer review) is the author/funder, who has granted medRxiv a license to display the preprint in perpetuity.

01455-4

29. Bilan N, Dastranji A, Ghalehgolab Behbahani A. Comparison of the spo2/fio2 ratio and the pao2/fio2 ratio in patients with acute lung injury or acute respiratory distress syndrome. Journal of Cardiovascular and Thoracic Research. 2015;7(1):28-31.

30. AmericanHeartAssociation-CPRandFirstAidEmer-gency Cardiovascular Care. Oxygenation and Ventilation of COVID19 Patients Module 4:

Ventilation Manage-

ment

https://cpr.heart.org/en/resources/coronaviruscovid19-

resources-for-cpr-training/oxygenation-and-ventilation-ofcovid-19-patients

31. Determinants of pulse wave velocity in healthy people and in the presence of cardiovascular risk factors: establishing normal and reference values' The Reference Values for Arterial Stiffness' Collaboration European Heart Journal doi:10.1093/eurheartj/ehq165

32. IanB.Wilkinson, Helen MacCallum, LauraFlint, John

R. Cockcroft, David E. Newby and David J. Webb the influence of heart rate on augmentation index and central arterial pressure in humans Journal of Physiology (2000), 525.1,pp.263-270

33. Varga et al. Endothelial cell infection and Endotheliitis in COVID-19 The Lancet VOLUME 395, ISSUE 10234, P14171418,MAY02,2020

34.Chen $\mathrm{T}$ et al. Clinical characteristics of 113 deceased patients with coronavirus disease 2019: retrospective study. BMJ2020;368:m1091.

35. Bellosta R, Luzzani L, Natalini G, et al. Acute limb ischemia in patients with COVID-19 pneumonia published online ahead of print, 2020 Apr 29. J Vasc Surg. 2020; S0741-5214(20)31080-6.

36.Bermejo-Martin JF, Almansa R, et al. COVID-19 as a cardiovascular disease: the potential role of chronic endothelial dysfunction, Cardiovascular Research, Vol- ume 116, Issue 10, 1 August 2020, Pages e132-e133, https://doi.org/10.1093/cvr/cvaa1401.

37. http://www.arterysociety.org/our-activities-2/cartesian-2/ 
medRxiv preprint doi: https://doi.org/10.1101/2020.12.18.20248317; this version posted December 19, 2020. The copyright holder for this preprint (which was not certified by peer review) is the author/funder, who has granted medRxiv a license to display the preprint in perpetuity. All rights reserved. No reuse allowed without permission.

A Evidence before thisstudy

\section{Research in context}

A. Evidence before this study. Theexactnature of theSARS-CoV-2viralinfectionanditsmanifestationasCOVID-19 diseaseis a matter ofan ongoing discussion. Based on priorknowledge, itcan besafelystated that COVID-19is not solelya Respiratory system disease involvinglungs. It also affects other bodily systems with target organ damage like Cardiovascular (Heart), Nervous system (Brain),Digestive(Bowels)aswellasRenal(Kidneys). Thecommonfactorinallthesesystemsisthe vascularEndotheliallayerinvarious forms. Pathological and clinical case study findings have shown Endotheliitis pervasive in COVID-19 cases. This leads to the hypothesis that acute functional compromise of vasculature leads to failure of various sys- tems and organs in severe COVID-19 patients.Controlandreversalofthisdamagemayreducethemorbidityandmortalityrisk.

B. Added value of this study. Although there is some pathological evidence of structural damage to the endothelial layer in COVID-19patients, thesystemicfunctionaldeteriorationinthevasculaturehasnotbeenstudied. Ourstudyisfirstofits kindtoprove the functional deterioration of Arterial system interms ofabnormal increase in arterialstiffnessastheprobable cause of severity in COVID-19. Our findings strongly suggest that arterial stiffness can be an independent and accurate marker for objective risk stratification and therapeutic alleviation of acute cardiovascular complications like MODS ( multiple organ distress syndrome ) in COVID-19.

C. Implications of all the available evidence. The basis of our study and its findings suggest that arterial stiffness measurement can be added as a simple and accurate measurement for objective risk stratification in COVID-19 patients. Early detection, monitoring and therapeutic control of Arterial Stiffness in COVID-19 patients may reduce acute cardiovascular complications. ArterialstiffnessmaybeusedasanindependentmarkerfortreatmentandprognosisinCOVID-19patients. 